GRZEGORZ BARTOSZEWSKI

RENATA SLOMNICKA

HELENA OLCZAK-WOLTMAN

ALEKSANDRA KORZENIEWSKA

TERESA GALECKA

KAROLINA KAŹMIŃSKA

KATARZYNA NIEMIROWICZ-SZCZYTT

Katedra Genetyki Hodowli i Biotechnologii Roślin, Wydział Ogrodnictwa Biotechnologii i Architektury Krajobrazu, Szkoła Główna Gospodarstwa Wiejskiego w Warszawie

Kierownik tematu: dr hab. Grzegorz Bartoszewski prof. Katedra Genetyki Hodowli i Biotechnologii Roślin, Wydział Ogrodnictwa Biotechnologii i Architektury Krajobrazu, Szkoła Główna Gospodarstwa Wiejskiego w Warszawie, ul. Nowoursynowska 159, 02-776 Warszawa, tel. 225932177 ,

e-mail: grzegorz_bartoszewski@sggw.pl

Prace zostaty wykonane $w$ ramach badań podstawowych na rzecz postępu biologicznego $w$ produkcji roślinnej na podstawie decyzji Ministra Rolnictwa $i$ Rozwoju Wsi nr HOR.hn.802.17.2018, Zadanie 100.

\title{
Doskonalenie ogórka (Cucumis sativus L.) pod względem odporności na kanciastą plamistość
}

\section{Improvement of cucumber (Cucumis sativus L.) in terms of angular leaf spot resistance}

Słowa kluczowe: Cucumis sativus L., P. syringae pv. lachrymans, resistance, QTL, RNA-seq

\section{CEL ZADANIA}

Celem badań w 2018 roku była konstrukcja ulepszonej mapy genetycznej ogórka i jej zagęszczenie w rejonach loci odporności na kanciastą plamistość. Opracowano zestaw nowych markerów PCR i SSR, a następnie wykorzystano je do genotypowania populacji mapującej Gy14×B10. Przeprowadzono bioinformatyczną analizę funkcjonalną genów ulegających zróżnicowanej ekspresji po zainfekowaniu roślin ogórka $P$. syringae pv. lachrymans i wykonano analizę ekspresji Real-Time PCR dla wybranych genów.

\section{WYNIKI}

Wykorzystując skonstruowaną dla populacji mapującej Gy14×B10 mapę genetyczną i sekwencje markerów flankujących loci odporności na kanciastą plamistość oraz 
dostępność sekwencji genomów linii rodzicielskich zidentyfikowano rejon genomu ogórka zawierający główny psl odporności ps15.1. W przypadku genomu wrażliwej linii B10 zidentyfikowano ciągłą sekwencję odpowiadającą ps15.1 o długości $895 \mathrm{kpz}$, zaś u linii odpornej Gy14 zidentyfikowano kontigi sekwencyjne reprezentujące ten rejon. W wyniku przyrównania wskazano insercje-delecje różnicujące te linie. Spośród różnic zidentyfikowanych in silico, dla 30 indeli uzyskano wydajną amplifikację PCR, polimorficzne na liniach rodzicielskich były 24 markery, a w obrębie 8 linii RIL 23 markery. Ostatecznie 19 markerów segregowało zgodnie z oczekiwaniami 1:1 na całej populacji mapującej, co potwierdziło ich przydatność do mapowania.

Skonstruowano ulepszoną mapę genetyczną dla populacji mapującej Gy14×B10, składającą się z 7 grup sprzężeń odpowiadających chromosomom ogórka. Całkowita długość mapy wyniosła 599,9 cM. Łącznie na mapę naniesiono 717 markerów SSR i DArTseq, z czego 123 markery na chromosomie 5 ogórka, a średnia odległością między markerami wyniosła $0,84 \mathrm{cM}$. Na podstawie oceny obecności chlorotycznego halo wokół uszkodzeń chorobowych na liściach zmapowano gen $\mathrm{psl}$ na chromosomie $5 \mathrm{w}$ pozycji $2,0 \mathrm{cM}$ i dwa loci QTL związane z ilościowym nasileniem objawów psl 5.1 i psl5.2. Gen psl ulokował się w obrębie locus psl5.1 (Słomnicka i in., 2018). Podjęto próbę zagęszczenia mapy w obrębie loci odporności na kanciastą plamistość, wykorzystując nowe markery. Finalnie na mapę naniesiono 13 markerów, które zagęściły głównie obszar wokół genu psl i locus psl5.1. Zagęszczanie mapy genetycznej spowodowało jednak jej rozciągnięcie i nie udało się zawęzić regionu genomu związanego z odpornością na kanciastą plamistość. Markerami najbliżej sprzężonymi z loci odporności były markery: UW085415, 16327616, IS_16325300, IS_16326693i P066_SSR. Markery te mogą w przyszłości znaleźć zastosowanie w hodowli ogórka, gdzie źródłem odporności jest linia Gy14 lub linie hodowlane wywodzące się z tej linii.

W wyniku sekwencjonowania RNA-seq uzyskano profile transkrypcyjne dla linii Gy14 i B10 w trzech punktach czasowych: przed inokulacją oraz dzień i trzy dni po inokulacji $(0,1$ i 3 dpi) a następnie zidentyfikowano geny ulegające zróżnicowanej ekspresji w pierwszych stadiach kanciastej plamistości. Stwierdzono, że znacznie więcej genów ulegało zmianom ekspresji w przypadku linii odpornej Gy14 (4268 genów w pierwszym dniu i $4654 \mathrm{w}$ trzecim dniu po infekcji) w porównaniu z linią podatną B10 (o 40\% mniej genów w 1 dniu i o 15\% mniej w 3 dniu po infekcji). Sugeruje to bardziej złożoną odpowiedź obronną linii odpornej na porażenie $P$. syringae pv. lachrymans w porównaniu $z$ linią podatną. Dla genów ulegających zróżnicowanej ekspresji wykonano analizy funkcjonalne. Stwierdzono, że największą grupę stanowią geny związane z procesami metabolicznymi i komórkowymi, kodujące białka o właściwościach katalitycznych i posiadających zdolność wiązania kofaktorów (Olczak-Woltman i in., 2018). Dla wybranych genów ulegających zróżnicowanej ekspresji wykonano analizy BLAST i wykazano, że ich produkty mogą być zaangażowane w biosyntezę hormonów roślinnych, reakcje obronne i inne procesy. Dla 30 wybranych genów wykonano analizy Real-Time PCR, które potwierdziły zróżnicowaną ekspresję genów w pierwszych stadiach kanciastej plamistości. Badane geny prezentowały różne profile ekspresji, co pozwala wskazać niektóre $\mathrm{z}$ nich jako potencjalne markery ekspresyjne stresu 
biotycznego u ogórka. Jako gen kandydacki markera wczesnej reakcji ogórka na stres można wskazać gen kodujący białko dehydrynowe DHN19, którego ekspresja wzrastała w pierwszym, a spadała w trzecim dniu po inokulacji. Geny kodujące białka PR-1 i PR-4 związane z patogenezą można wskazać jako geny kandydackie markerów późnej odpowiedzi na stres biotyczny, gdyż ich ekspresja przed inokulacją i jeden dzień po inokulacji była bliska zeru, natomiast dynamicznie wzrastała $\mathrm{w}$ trzecim dniu po inokulacji.

\section{WNIOSKI}

1. Dostępność sekwencji genomów linii Gy14 i B10 ogórka umożliwia identyfikację nowych markerów molekularnych w rejonie loci odporności na kanciastą plamistość.

2. Wszystkie zidentyfikowane w populacji mapującej Gy14×B10 loci odporności na kanciastą plamistość zmapowano w tym samym rejonie genomu ogórka na górnym ramieniu chromosomu 5.

3. Zidentyfikowane markery sprzężone z loci odporności na kanciastą plamistość mogą znaleźć potencjalne zastosowanie w hodowli ogórka, gdzie źródłem odporności jest linia Gy14 lub wyprowadzone z niej linie hodowlane.

4. Analizy funkcjonalne wykonane dla genów ogórka ulegających zróżnicowanej ekspresji we wczesnych etapach przebiegu kanciastej plamistości pokazały, że wśród tych genów najliczniejsza jest grupa genów kodujących białka związane z procesami metabolicznymi i komórkowymi o właściwościach katalitycznych.

5. Geny kodujące dehydrynę DHN19 i białka związane z patogenezą PR-1 i PR-4 są interesującymi genami kandydackimi na markery ekspresyjne stresu u ogórka.

\section{LITERATURA}

Olczak-Woltman H., Słomnicka R., Bartoszewski G. 2018. Transcriptomic response of resistant and susceptible cucumber lines to Pseudomonas syringae pv. lachrymans infection. Proc XIX Diagmol Conference on Molecular biology in diagnostics of infectious diseases and biotechnology, WULS, November 17, 2018, Warsaw, Poland: 90 - 93.

Słomnicka R., Olczak-Woltman H., Korzeniewska A., Gozdowski D., Niemirowicz-Szczytt K., Bartoszewski G. 2018. Genetic mapping of psl locus and quantitative trait loci for angular leaf spot resistance in cucumber (Cucumis sativus L.) Mol. Breed. 38: 111. 
